3 Wood, C. H., and Roach, S. A., British fournal of Industrial Medicine, $1964,21,180$.

4 Molyneux, M. K. B., and Tombleson, J. B. L., British fournal of Industrial Medicine, 1970, 27, 225.

5 Fox, A. J., et al., British fournal of Industrial Medicine, 1973, 30, 42.

- Merchant, J. A., et al., Fournal of Occupational Medicine, 1973, 15, 212. Statutory Instruments, The National Insurance (Industrial Injuries) Mekky, S., Roach, S. A., and Schilling, R S. F., British Fournal of Industrial Medicine, 1967, 24, 123.

Department of Health and Social Security in Social Security Statistics, 1972. London, H.M.S.O., 1973.

10 Merchant, J. A., et al., fournal of Occupational Medicine, 1973, 15, 222.

11 Merchant, J. A., et al., fournal of Occupational Medicine, 1973, 15, 222. of Industrial Medicine, 1974, 31, 18.
.

12 NIOSH Cotton Dust Criteria Document, HEW Publication No. (NIOSH) 75-18. U.S. Government Printing Office, 1974.

13 British Occupational Hygiene Society, Annals of Occupational Hygiene, $1972,15,165$.

14 Merchant, J. A., et al., British Fournal of Industrial Medicine, 1973, 30, 237.

15 Imbus, H. R., and Suh, M. W., British fournal of Industrial Medicine, 1974, 31, 209.

${ }^{16}$ Merchant, J. A., et al., British fournal of Industrial Medicine, 1974, 31, 261.

\section{Ethics of Selective Abortion}

Prenatal diagnosis of fetal abnormality requires a sample of amniotic fluid to be removed at 15-16 weeks gestation, and a further 2-3 weeks of tissue culture is needed before a satisfactory chromosomal diagnosis can be made. If the fetus is shown to be abnormal and termination of pregnancy recommended, inevitably the procedure has to be carried out late in the mid-trimester. When the risks of such an operation are added to the $1-2 \%$ chance that the amniocentesis may precipitate a spontaneous abortion it is clear that prenatal diagnosis is far from a trivial investigation. Nevertheless, specialist centres throughout Britain are now offering diagnostic amniocentesis when there are grounds for suspecting that the fetus may have a serious genetic disorder-either the birth of a previous abnormal child to the parents or a family history of abnormality. The four main categories are chromosomal abnormalities such as Down's syndrome; X-linked disorders, such as Duchenne muscular dystrophy, where determination of the sex of the fetus is a guide for action; metabolic disorders, such as Tay-Sachs's disease, in which the diagnosis depends on assay of a specific enzyme; and malformations such as spina bifida in which a raised alpha-fetoprotein level is almost certainly diagnostic.

The ethical problems raised by this new area of medicine have been discussed by Professor Harry Harris in his Rock Carling lecture. ${ }^{1}$ Some authorities-including Lejeune, ${ }^{2}$ the discoverer of the chromosomal basis of Down's syndromehave taken the view that any selective abortion is morally indefensible. More prevalent is the opinion that the rights of the fetus should be balanced against those of the mother and the rest of the family; so that if the abortion of a fetus with Down's syndrome is homicide then, as Harris says, it is an ethically acceptable form of homicide.

When the genetic defect produces severe, unremediable physical or mental handicap the issues are clear cut. Much more difficult are disorders such as haemophilia, for which treatment is now available which can prevent severe disability; but in such conditions parents of one haemophiliac son might feel prepared to take on another child only if they could be certain it would not be affected.

Need society be concerned on eugenic grounds? With recessive disorders selective abortion is likely to lead to an increase in the number of abnormal genes in the population, since affected fetuses will be replaced by normal ones until the family reaches the wanted size. Two-thirds of these healthy children will be heterozygotes; the affected fetuses, who would have died without reproducing and so could not have contributed genes to the next generation, will be replaced by healthy heterozygotes who could. Calculations suggest that such an effect will be very small for autosomal recessive genes but could be much larger if selective abortion was practised widely for X-linked abnormalities.

Two other theoretical problems are presented by selective abortion. Its widespread use might reduce the tolerance shown by society to living defectives. A child with haemophilia or muscular dystrophy living in a society in which most of his potential fellow-sufferers had been destroyed prenatally might be seen by the community as one unfit to be alive. It could also be argued that the ethical justifications for destroying a defective fetus might apply just as well to destruction of a newborn defective child. Could we be at the top of a slippery slope?

Harris's conclusion is emphatic. "It is no mean achievement to be able to offer to parents who have already had a child with a severe autosomal recessive abnormality such as Tay-Sachs's disease the opportunity of being certain their next child will not suffer from this condition. Previously all they could have been told was that there was a 1 in 4 chance that any future child would have the same abnormality." When benefits of this kind can be offered to parents ethical arguments are not likely to stand long in the way of further development of prenatal diagnosis and selective abortion.

\footnotetext{
1 Harris, H., Prenatal Diagnosis and Selective Abortion, London, Nuffield Provincial Hospitals Trust, 1974.
}

2 Lejeune, J., American fournal of Human Genetics, 1970, 22, 121.

\section{Bone Marrow Transplants in Leukaemia}

For more than 20 years it has been known that animals given a supralethal dose of total body irradiation (T.B.I.) can be saved from marrow aplasia by an infusion of syngeneic marrow cells. ${ }^{1}$ The value of this approach was first confirmed in a man who had received an otherwise lethal dose of T.B.I. accidentally; the marrow graft from his genetically identical twin was life saving. ${ }^{2}$ In theory patients with severe marrow hypoplasia from other causes could be supported in a similar manner, and indeed success using this procedure has now been reported from several centres.

One group in Seattle has reported 16 bone-marrow transplants between identical twins where the recipients were suffering from various forms of acute leukaemia and were considered to be in the terminal phase of their disease. ${ }^{3}$ Seven patients had myeloblastic leukaemia, seven lymphoblastic, and two had a blast crisis complicating chronic granulocytic leukaemia. All patients were treated with chemotherapy including high dose cyclophosphamide and T.B.I. (1,000 rads) before marrow grafting. The median duration of stay in hospital after the graft was only 24 days, and patients were managed using conventional reverse-barrier nursing techniques without the help of protected environments. Of the 16 patients treated, 14 achieved a complete remission and six are still in complete remission at 11-44 months without maintenance chemotherapy. Both patients with blast crises in chronic granulocytic leukaemia relapsed at 3-5 months, but the relatively long remissions in some of the other patients suggest that this approach is of value in selected cases-and 